\title{
Addition of different probiotics to commercial feeds for piglets during the nursery phase
}

\section{Adição de diferentes probióticos em dietas comerciais para leitões durante a fase de creche}

\author{
Newton Tavares Escocard de Oliveira ${ }^{1}$; Paulo Levi de Oliveira Carvalho ${ }^{1 *}$; Jansller \\ Luiz Genova²; Eliseu Carlos Cristofori²; Fábio Henrique Rodrigues Silveira ${ }^{2}$; \\ Osiris Antunes de Caxias Junior²; Ana Lúcia Almeida Santana ${ }^{3}$
}

\begin{abstract}
In this study, we aimed to evaluate the effect of the addition of different probiotics to commercial diets for piglets on diet digestibility, total bacterial count (TBC) of faeces, Clostridium count and growth performance. In the digestibility assay, 24 entire male pigs with an average initial body weight of 18.8 $\pm 0.87 \mathrm{~kg}$ were housed individually in metabolism cages and distributed in a completely randomised experimental design; this consisted of three treatments (probiotic-free commercial feed; commercial feed with the addition of $0.2 \%$ probiotic containing a blend of microorganisms; commercial feed with the addition of $0.1 \%$ yeast-based probiotic Saccharomyces cerevisiae boulardii) and eight replicates. The digestibility of the feeds was determined. At the end of the experiment, 25 grams of faeces were collected for microbiological analysis. In the subsequent experiment, 150 crossbred piglets (entire males and females), weaned at 21 days of age and having an average initial body weight of $6.81 \pm$ $0.71 \mathrm{~kg}$ were distributed in a randomised complete block design, with six treatments repeated twice in the first and thrice in the second block, totaling five replicates and five pigs per experimental unit. The treatments, arranged in a $3 \times 2$ factorial arrangement, consisted of a combination of the three experimental diets used in the digestibility test and two genders. The growth performance in the nursery was evaluated during the following phases: pre-starter I (21 to 29 days), pre-starter I and II (21 to 40 days) and the total period ( 21 to 63 days). There was an effect $(\mathrm{p}<0.05)$ of the diets on the digestible protein and the logarithm of the TBC. There was no effect $(\mathrm{p}>0.05)$ of the interaction or the diets on the growth performance of the pigs in any of the phases. Both in the entire experimental period and in the pre-starter I and II phases, male pigs presented better feed conversion $(p<0.05)$ than females. There was an improvement in the apparent digestibility of the crude protein of the feed when the pigs were fed commercial feed containing probiotics. Pigs fed commercial feed containing probiotics based on yeast Saccharomyces cerevisiae boulardii presented a reduced TBC in their faeces. Commercial feed containing probiotics did not influence the growth performance parameters of nursery phase piglets.
\end{abstract}

Key words: Additives. Growth performance. Lactobacillus. Microbiology. Saccharomyces. Yeast.

\footnotetext{
1 Profs., Curso de Zootecnia, Universidade Estadual do Oeste do Paraná, UNIOESTE, Marechal Cândido Rondon, PR, Brasil. E-mail: newtonescocard@hotmail.com; paulolevi@yahoo.com.br

2 Mestres em Zootecnia, UNIOESTE, Marechal Cândido Rondon, PR, Brasil.E-mail: jansllerg@gmail.com; eliseu_crf@hotmail. com; fabiohenrique.vet@hotmail.com; osiriscaxiasjr@gmail.com

3 Prof ${ }^{a}$, Instituto de Ciências Agrárias, Universidade Federal dos Vales do Jequitinhonha e Mucurí, UFVJM, Unaí, MG, Brasil. E-mail: zootecana@gmail.com

* Author for correspondence
} 


\section{Resumo}

Neste estudo, nosso objetivo foi o de avaliar o efeito da adição de diferentes probióticos em dietas comerciais para leitões sobre a digestibilidade da dieta, a contagem bacteriana total de fezes (CBT), a contagem de clostrídeos e o desempenho zootécnico. No ensaio de digestibilidade, foram utilizados 24 suínos machos inteiros, com peso corporal inicial de $18,8 \pm 0,87 \mathrm{~kg}$, os quais foram alojados individualmente em gaiolas de metabolismo e distribuídos em um delineamento experimental inteiramente casualizado, constituído de três tratamentos (ração comercial isenta de probiótico; ração comercial com adição de $0,2 \%$ de probiótico contendo um blend de microrganismos e ração comercial com adição de $0,1 \%$ de probiótico à base de levedura Saccharomyces cerevisiae boulardii) e oito repetições. Foi determinada a digestibilidade das rações e ao final do experimento foram coletados 25 gramas de fezes para análise microbiológica. No experimento subsequente, foram utilizados 150 leitões (machos inteiros e fêmeas mestiços), desmamados aos 21 dias de idade e com peso corporal médio inicial de $6,81 \pm 0,71 \mathrm{~kg}$, os quais foram distribuídos em um delineamento experimental de blocos casualizados, com seis tratamentos repetidos duas vezes no primeiro e três vezes no segundo bloco, constituídos no tempo, totalizando cinco repetições e cinco suínos por unidade experimental. Os tratamentos, dispostos em arranjo fatorial $3 \times 2$, foram constituídos da combinação de três dietas experimentais, as utilizadas no ensaio de digestibilidade, e dois sexos. Foi avaliado o desempenho na creche, durante as fases pré-inicial I ( 21 a 29 dias), pré-inicial I e II ( 21 a 40 dias) e período total (21 a 63 dias). Houve efeito $(\mathrm{p}<0,05)$ de dietas sobre a proteína digestível e no logaritmo da CBT. Não houve efeito $(p>0,05)$ de interação e de dietas sobre o desempenho dos suínos em nenhuma das fases. No período total e na fase pré-inicial I e II, os suínos machos apresentaram melhor conversão alimentar (p $<0,05)$ do que as fêmeas. Há uma melhora sobre a digestibilidade aparente da proteína bruta da ração quando os suínos são alimentados com ração comercial contendo probióticos. Suínos alimentados com ração comercial contendo probiótico à base da levedura Saccharomyces cerevisiae boulardii apresentam redução da contagem bacteriana total nas fezes. Ração comercial contendo probióticos não influencia nos parâmetros de desempenho de leitões em fase de creche.

Palavras-chave: Aditivos. Desempenho zootécnico. Lactobacillus. Microbiologia. Saccharomyces. Levedura.

\section{Introduction}

The nursery phase is considered the most critical period for production swine, as the piglets suffer enormous stress due to factors such as separation from their mother, adaptation to a new environment, change in diet and social stress. In addition to these changes, the acquired protection of breast milk, via immunoglobulin intake, is withdrawn from the piglet, which has not yet fully developed active immunity.

The dynamics of the intestinal microbiota have a direct influence on host health, causing metabolic, physiological, nutritional and immunological changes (KOTZAMPASSI; GIAMARELLOS, 2012; POWER et al., 2014). Researchers have studied the use of alternative foods and beneficial microorganisms that can be added to the diet of piglets to benefit intestinal microbiota, such as probiotics.

To be considered a probiotic, the microorganism should present certain characteristics, such as being part of the host's normal intestinal flora, being able to survive and colonise the host, being able to adhere to the intestinal epithelium and survive the action of digestive enzymes, having an antagonistic action against pathogenic microorganisms, not being toxic or pathogenic, being cultivable on an industrial scale, being stable and viable in commercial preparation, and able to stimulate immunity (BRITO et al., 2013).

When added to non-ruminant feed, probiotics may act by increasing weight gain and improving feed conversion. This increase in growth performance may occur as probiotics reduce 
contamination by pathogens in the gastrointestinal tract of the animal, mainly Salmonella spp., and improve immunity (YANG et al., 2015). Probiotics have immunomodulatory action in the host, which occurs due to the production of glycopeptides or other metabolites. They also have a nutritional effect by stimulating the production of enzymes such as lactase and help maintain healthy intestinal villi, improving food digestibility and nutrient uptake (ROBLES-HUYANATE et al., 2014).

When assessing the growth performance of piglets in the starter phase using Enterococcus faecium as a dietary probiotic, Lojanica et al. (2010) found better feed conversion in relation to the control treatment (1.78 and 2.38, respectively), higher daily weight gain (459 and $327 \mathrm{~g}$, respectively), and lower mortality (2.65 and 4.76\% respectively). Giang et al. (2012) also found positive values for performance, feed digestibility and incidence of diarrhoea in piglets in the nursery phase when using probiotics in the diet. On the other hand, Wang et al. (2009) found no significant improvement in growth performance using the probiotics Lactobacillus acidophilus and Pediococcus acidilactici in pig diets.

Thus, the objective of the present study was to evaluate the effect of the addition of different probiotics to commercial piglet diets on the diet digestibility, total bacterial count (TBC) of faeces, clostridium count and growth performance.

\section{Material and Methods}

This experiment was carried out at the Swine Sector of the Experimental Station Nucleus of the State University of Western Paraná, Unioeste, Campus of Marechal Cândido Rondon, Paraná.

\section{Experimental design, animals, housing and diets}

In the digestibility assay (Experiment 1), a total of 24 crossbred entire male pigs, with an initial average body weight of $18.80 \pm 0.87 \mathrm{~kg}$, were distributed in a randomised complete block design with three treatments and eight replicates, totaling 24 experimental units. The blocks were based on initial body weight.

The animals were housed individually in metabolic cages similar to those described previously by Pekas (1968). They remained in these cages for 12 days, with 7 days for acclimation to the cages and feed and 5 days for the collection of faeces and urine.

During the acclimation phase, the animals received two meals per day, provided at 8:00 a.m. and 3:00 p.m. The total daily amount of food provided during the collection period was determined from the acclimation period, based on the animals' voluntary consumption and metabolic weight $\left(\mathrm{BW}^{0.75}\right)$. The feed was moistened with water ( $20 \%$ by total weight of feed) to avoid waste, reduce powdery properties and improve palatability. After each meal, water was supplied through a feeder at a rate of $3 \mathrm{~mL} / \mathrm{g}$ of feed consumed; the quantity was calculated for each experimental unit to avoid excess water consumption.

The experimental treatments were composed of: probiotic-free commercial feed; commercial feed with the addition of $0.2 \%$ probiotic containing a blend of microorganisms; and commercial feed with the addition of $0.1 \%$ yeast-based probiotic Saccharomyces cerevisiae boulardii. The feed was provided by a local company (Table 1) and the guaranteed levels of nutrients were similar to the levels reported by Rostagno et al. (2011). The physicochemical composition of all tested ingredients was determined using the NIRS ${ }^{\mathrm{TM}}$ DS2500 F analyzer. The results were similar to those found in the Brazilian Tables for Poultry and Swine: food composition and nutritional requirements (ROSTAGNO et al., 2011).

Probiotic A was composed of: Lactobacillus plantarium $\left(1.26 \times 10^{8}\right)$, L. bulgaricus $\left(2.06 \times 10^{8}\right)$, L. acidophilus $\left(2.06 \times 10^{8}\right)$, L. rhamnosus $\left(2.06 \times 10^{8}\right)$, 
Bifidobacterium bifidum $\left(2.00 \times 10^{8}\right)$, Streptococcus thermophilus $\left(4.10 \mathrm{x} 10^{8}\right)$ and Enterococcus faecium $\left(6.46 \times 10^{8}\right)$. Probiotic B consisted of yeast Saccharomyces cerevisiae boulardii, with a minimum guarantee of $2.0 \times 10^{10} \mathrm{CFU} / \mathrm{g}$.

For the growth performance trial (Exp. 2), 150 crossbred piglets (entire males and females), aged 21 days with an initial average body weight of $6.81 \pm 0.71 \mathrm{~kg}$, were distributed in a completely randomised design, in a $2 \times 3$ factorial arrangement (two genders and three feeds) repeated twice in the first and thrice in the second block, with five replicates of five piglets per experimental unit. The block was considered each experimental round.

The animals were identified with numbered eartags and housed in suspended nursery pens (1.32 $\mathrm{m}^{2}$ ), with polyethylene plastic flooring, equipped with nipple-type drinking fountains and semiautomatic feeders. The nursery pens were located in a masonry shed with concrete flooring, ceramic roof tiles and a heating system with lamps. Feed and water were provided ad libitum throughout the experimental period.

Table 1. Centesimal and chemical composition of experimental diets for piglets in nursery phase in Exp 1 and 2.

\begin{tabular}{|c|c|c|c|}
\hline \multirow[b]{2}{*}{ Item } & \multicolumn{3}{|c|}{ Experimental phases $^{1)}(6.81$ to $22.36 \mathrm{~kg})$} \\
\hline & PI & PII & $\mathbf{S}$ \\
\hline Corn & 49.15 & 55.20 & 59.80 \\
\hline Soybean meal & 18.00 & 25.00 & 30.00 \\
\hline Soybean oil & 3.35 & 2.80 & 2.70 \\
\hline Fish meal & 3.50 & 3.00 & 1.50 \\
\hline Nucleus $^{3)}$ & 26.00 & 14.00 & 6.00 \\
\hline \multirow[t]{2}{*}{ Total (\%) } & 100.0 & 100.0 & 100.0 \\
\hline & \multicolumn{3}{|c|}{ Calculated composition } \\
\hline Crude protein $(\%)$ & 18.50 & 19.00 & 20.00 \\
\hline Lactose (\%) & 7.10 & 2.60 & - \\
\hline Metabolizable energy (kcal/kg) & 3,55 & 3,42 & 3,40 \\
\hline Digestible lysine (\%) & 1.37 & 1.34 & 1.32 \\
\hline Digestible methionine (\%) & 0.52 & 0.52 & 0.48 \\
\hline Total calcium (\%) & 0.55 & 0.70 & 0.72 \\
\hline Available phosphorus (\%) & 0.39 & 0.35 & 0.34 \\
\hline Sodium (\%) & 0.28 & 0.23 & 0.24 \\
\hline
\end{tabular}

1) PI and PII: pre-starter I and II; S: starter. The diets were the same changing only in the addition of the probiotic $0.1 \%$ and $0.2 \%$. ${ }^{2)}$ Composition per phase (levels of warranty): PI, PII and S (g/kg), respectively: Humidity maximum ${ }^{(100.0 ; 100.0 ; 120.0)}$, Crude protein minimum ${ }^{(190.0 ; 200.0 ; 200.0)}$, Ether extract minimum ${ }^{(70.0 ; 60.0 ; 50.0)}$, Mineral matter maximum ${ }^{(55.0 ; 55.0 ; 60.0)}$, Average chain fatty acid minimum ${ }^{(3.8 ; 3.8 ;-)^{*}}$, Lysine minimum ${ }^{(14.5 ; 13.0 ; 13.5)}$, Methionine minimum ${ }^{(5.0 ; 4.0 ; 4.85)}$, Crude fiber maximum ${ }^{(30.0 ; 50.0 ; 35.0)}$, Calcium ${ }^{(6.0 \text { to } 7.0 ; 5.5 \text { to } 7.0 ; 8.0 \text { to }}$ 9.0) Phosphorus ${ }^{(5.0 ; 5.0 ; 6.0)}$, Sodium ${ }^{(3.3 ; 2.7 ; 2.7)}$. *Trace (-):Value not reported on the label of the feed or absence.

${ }^{3)}$ Minimum level of microminerals and vitamins (mg/kg): Folic acid ${ }^{(0.65)}$, Pantothenic acid ${ }^{(13.72)}$, Cobalt ${ }^{(0.140)}$, Copper ${ }^{(9,500)}$, Iron ${ }^{(120)}$, Iodine ${ }^{(1.20)}$, Niacin ${ }^{(33.0)}$, Selenium ${ }^{(0.30)}$, Manganese ${ }^{(30.0)}$, Vitamin $\mathrm{B}_{1}{ }^{(1.29)}$, Vitamin $\mathrm{B}_{2}{ }^{(8.32)}$, Vitamin $\mathrm{B}_{6}{ }^{(3.90)}$, Vitamin $\mathrm{K}_{3}{ }^{(1.65)}$, Zinc ${ }^{(2,137)}$.

The experimental feeds (those used in the digestibility test) were composed of: probioticfree commercial feed; commercial feed with the addition of $0.2 \%$ probiotic containing a blend of microorganisms; and commercial feed with the addition of $0.1 \%$ yeast-based probiotic Saccharomyces cerevisiae boulardii. The feed was provided by a local company (Table 1) and the 
guaranteed levels of nutrients were similar to the levels reported by Rostagno et al. (2011).

All piglets received a pre-weaning feed in order to reduce weaning stress. During the experimental period, three types of feed were used, corresponding to each phase of the animals: pre-starter I feed (21 to 29 days of age), pre-starter II feed (30 to 40 days of age) and starter feed (41 to 63 days of age). The feed was composed of corn, soybean meal, fish meal, soybean oil, blood plasma, dry chicory pulp, extruded soybeans, whey powder, dicalcium phosphate, lysine, methionine, threonine, tryptophan and vitamins $\mathrm{A}, \mathrm{B}_{1}, \mathrm{~B}_{2}, \mathrm{~B}_{6}, \mathrm{~B}_{12}, \mathrm{D}_{3}, \mathrm{E}$ and $\mathrm{K}_{3}$. The starter feed did not contain ingredients of animal origin. The composition of the probiotics and the dosage used were the same as those in the digestibility assay.

\section{Sample collection and preparation}

In the digestibility assay, the amount of feed supplied and the faeces and urine sample collection followed the methods previously described by Sakomura and Rostagno (2016). During the collection period, $1 \%$ ferric oxide $\left(\mathrm{Fe}_{2} \mathrm{O}_{3}\right)$ was added to the feed to mark the beginning and end of faecal collection. Faeces were collected on a daily basis, weighed, placed in labelled plastic bags and stored in a freezer at $-18{ }^{\circ} \mathrm{C}$. After the collection period, faecal samples were thawed, homogenised, weighed on a digital scale and a composite sample (20\% by total weight of faeces) of the faeces collected from each experimental unit was removed. Composite samples were dried in a forced ventilation oven (55 ${ }^{\circ} \mathrm{C}$ ), ground in a Wiley-type grinder mill and stored in polyethylene pots for the analysis of dry matter (DM), organic matter (OM), mineral matter (MM), crude energy (CE) and crude protein (CP). Analyses were carried out at the Unioeste's Animal Nutrition Laboratory (LANA/Unioeste).

Urine was collected daily in plastic buckets containing $20 \mathrm{~mL}$ 1:1 $\mathrm{HCl}$ to avoid nitrogen volatilisation and bacterial proliferation. An aliquot
( $10 \%$ by the total volume of urine) was conditioned daily in polyethylene terephthalate (PET) bottles and frozen at $-18{ }^{\circ} \mathrm{C}$. Subsequently, these samples were homogenised and aliquots were taken for the determination of crude energy. All analyses of feed, urine and faeces were performed following the procedures previously reported by Silva and Queiroz (2002). Samples of $25 \mathrm{~g}$ were diluted prior to the quantification of the microbial populations, which was carried out using the technique of selective culture (SILVA et al., 1997).

\section{Analysed variables}

In Experiment 1, the dry matter digestibility coefficients (DMDC), organic matter (OMDC), crude protein (CPDC), gross energy (GEDC) and digestible nutrient $(\mathrm{DN})$ of the diet were determined. This was used to calculate the digestible protein (DP), digestible dry matter (DDM), digestible organic matter (DOM) and digestible diet energy (DDE), according to the procedures published by Matterson et al. (1965). The logarithm (base 10) of the total bacterial count (Log TBC) and Clostridium in the faeces (Log Clos) were also calculated.

In Experiment 2, leftover feed was collected, weighed and subtracted from the feed supplied to calculate daily feed intake. The individual weight of the animals was recorded on an electronic scale (Digitron ${ }^{\odot}$ brand, $50 \mathrm{~kg}$ capacity); this was recorded at the beginning and end of each experimental phase. Based on these data, average values were determined for daily feed intake (DFI, $\mathrm{kg} /$ day), daily weight gain (DWG, $\mathrm{kg} /$ day), feed conversion (FC, $\mathrm{kg} / \mathrm{kg}$ ) and final weight (FW, $\mathrm{kg} / \mathrm{phase}$ ) of the pre-starter I ( 21 to 29 days of age), pre-starter I and II ( 21 to 40 days of age) phases and the total period (21 to 63 days of age).

\section{Statistical analysis}

Before evaluating the results using an analysis of variance, the standardised residues analysis 
of Student (RStudent) was performed to identify outliers. The criterion adopted for the identification of outliers was based on a normal distribution curve; RStudent values greater than or equal to three standard deviations were considered influential. The normality of the experimental errors and the homogeneity of variances between the treatments for several variables were evaluated using ShapiroWilk and Levine tests, respectively. All parameters had a normal distribution and homogeneity of variances.

The statistical model used for the digestibility coefficients and digestible nutrients of the feed was $\mathrm{Y}_{\mathrm{ij}}=\mathrm{m}+\mathrm{T}_{\mathrm{i}}+\mathrm{b}_{\mathrm{j}}+\varepsilon_{\mathrm{ij}}$, wherein: $\mathrm{Y}_{\mathrm{ij}}=$ observation of the dependent variable in each plot, measured in the $i$-th class of probiotic, in the j-th block and in the $\mathrm{k}$-th replication; $\mathrm{m}=$ effect of the overall mean; $\mathrm{T}_{\mathrm{i}}=$ effect of classes of probiotic, for $i=(1,2$ and 3$) ; b_{j}$ $=$ block effect, for $\mathrm{j}=(1$ and 2$) ; \varepsilon_{\mathrm{ij}}=$ random errors of the plots associated with level $\mathrm{i}$, in the $\mathrm{j}$-th block and $\mathrm{k}$-th replicate, independent, homoscedastic and with a normal distribution.

The effects of the treatment classes on the dependent variables were determined using an analysis of variance (ANOVA). Treatment averages were compared using a t-test, based on the significance of the F-test from the ANOVA. A 5\% level of significance was adopted in all statistical analyses, using Statistical Analysis System software.

For the performance characteristics and microbiology, the following statistical model was used: $\mathrm{Y}_{\mathrm{ijkl}}=\mathrm{m}+\mathrm{P}_{\mathrm{i}}+\mathrm{S}_{\mathrm{j}}+\mathrm{PS}_{\mathrm{ij}}+\beta\left(\mathrm{X}_{\mathrm{ijk} \mathrm{l}}-\ldots\right)+\mathrm{b}_{\mathrm{l}}+$ $\varepsilon_{\mathrm{ijkl}}$. The initial weight of the animals was used as a covariate effect. The effects of the factors included in the model were represented by: $\mathrm{Y}_{\mathrm{ijkl}}=$ average observation of the dependent variable in each plot, measured in the $\mathrm{i}$-th probiotic source, in the $\mathrm{j}$-th gender class, in the k-th replicate and in 1-th block; $\mathrm{m}=$ effect of the overall mean; $\mathrm{P}_{\mathrm{i}}=$ effect of the class of probiotic source, for $\mathrm{i}=(1,2$ and 3$) ; \mathrm{S}_{\mathrm{j}}=$ effect of the gender classes, for $\mathrm{j}=(1$ and 2$)$; $\mathrm{PS}_{\mathrm{ij}}$ $=$ effect of the interaction between the $\mathrm{i}$-th class of probiotic source and the $\mathrm{j}$-th gender class; $\beta=$ regression coefficient of $\mathrm{Y}$ about $\mathrm{X} ; \mathrm{X}_{\mathrm{ijk} \mathrm{l}}=$ average observation of the covariate (initial weight) in each plot, measured in the $\mathrm{i}$-th probiotic class, $\mathrm{j}$-th gender class, $\mathrm{k}$-th replicate and 1-th block; ... $=$ overall average for the covariate $\mathrm{X} ; \mathrm{b}_{1}=$ block effect, for $1=$ (1 and 2); $\varepsilon_{\mathrm{ijkl}}=$ random error of the plot associated with level i, class $\mathrm{j}$, replication $\mathrm{k}$ and block 1 .

The effects of the probiotic source, gender and the interaction between the classes of probiotic source and gender on the dependent variables were determined using an analysis of variance (ANOVA). Comparisons between the averages of minimum squares (lsmeans), related to the effect of probiotic source and gender, were performed using a t-test and F-test at the 5\% probability level. Statistical analyses were performed using the "Proc Univariate" and "General Linear Models" procedures of the Statistical Analysis System software.

\section{Results}

\section{Digestibility assay}

The experimental errors of the characteristics presented a normal distribution of probabilities and homogeneities of variances of the treatments. There was no effect $(p>0.05)$ of the treatments on the variables DMDC, CPDC, GEDC, OMDC, DDM, DOM and DDE (Table 2). However, there was a treatment effect $(p<0.05)$ on DP: pigs receiving probiotics had better protein digestibility than animals fed a probiotic-free diet (Table 2). 
Table 2. Coefficients of apparent digestibility, values of nutrients and energy digestible of piglets in starter phase in $\operatorname{Exp} 1^{1}$.

\begin{tabular}{lcccc}
\hline Variables & Probiotic free & Probiotic A & Probiotic B & CV (\%) $)^{2}$ \\
\hline & \multicolumn{4}{c}{ Coefficients of apparent digestibility } \\
ADMDC (\%) & 92.38 & 92.29 & 92.25 & 1.119 \\
ACPDC (\%) & 91.26 & 90.99 & 91.37 & 1.518 \\
AOMDC (\%) & 92.63 & 92.41 & 92.59 & 1.102 \\
AGEDC (\%) & 93.28 & 93.16 & 93.13 & 0.981 \\
\hline & \multicolumn{4}{c}{ Values of nutrients and energy digestible } \\
DDM (\%) & 82.36 & 82.46 & 82.41 & 1.461 \\
DP (\%) & $17.12^{\mathrm{b}}$ & $17.83^{\mathrm{a}}$ & $18.11^{\mathrm{a}}$ & 1.517 \\
DOM (\%) & 88.25 & 88.17 & 88.12 & 0.974 \\
DDE (kcal/kg) & $4,108.2$ & $4,098.4$ & $4,123.2$ & 1.104 \\
\hline
\end{tabular}

1) Values followed by different lowercase letters, in row, differ according to t-test, at 5\% probability level; Treatments - Probiotic free: probiotic free commercial feed $(n=8)$, Probiotic A: commercial feed with addition of $0.2 \%$ probiotic containing a blend of microorganisms $(\mathrm{n}=7)$ and Probiotic B: commercial feed with addition of $0.1 \%$ yeast-based probiotic Saccharomyces cerevisiae boulardii $(\mathrm{n}=7)$.

${ }^{2)} \mathrm{CV}$ : coefficient of variation.

3) ADMDC: apparent dry matter digestibility coefficient, ACPDC: apparent crude protein digestibility coefficient, AOMDC: apparent organic matter digestibility coefficient, AGEDC: apparent gross energy digestibility coefficient.

4) DDM: digestible dry matter, DP: digestible protein, DOM: digestible organic matter, DDE: digestible diet energy.

\section{Microbiological analysis}

There was no effect of probiotic source $(p>0.05)$ on the log of the Clostridium count; however, there was an effect $(p<0.05)$ on the log of the TBC count
(Table 3). Piglets that received probiotics containing several species of microorganisms (Probiotic A) presented lower counts in relation to the piglets that did not receive probiotics in the diet.

Table 3. Lsmeans of the logarithm (base 10) of the total bacterial count and microbiological count for Clostridium in faeces of entire male piglets fed with different probiotics in $\operatorname{Exp} 1^{1}$.

\begin{tabular}{lcc}
\hline Probiotic source & Log Clostridium & Log TBC \\
\hline Probiotic free & $6.64\left(7.20 \times 10^{6}\right)$ & $7.37^{\mathrm{a}}\left(2.015 \times 10^{7}\right)$ \\
Probiotic A & $6.55\left(2.88 \times 10^{6}\right)$ & $6.69^{\mathrm{b}}\left(4.950 \times 10^{6}\right)$ \\
Probiotic B & $6.90\left(1,25 \times 10^{7}\right)$ & $6.91^{\mathrm{ab}}\left(1.145 \times 10^{7}\right)$ \\
\hline CV (\%) & 9.90 & 6.76 \\
\hline
\end{tabular}

1) Lsmeans values followed by different lowercase letters, in column, differ according to t-test, at 5\% probability level; Values in parentheses represent the median $(n=8)$ of the original variable;

Treatments - Probiotic free: probiotic free commercial feed, Probiotic A: commercial feed with addition of $0.2 \%$ probiotic containing a blend of microorganisms and Probiotic B: commercial feed with addition of $0.1 \%$ yeast-based probiotic Saccharomyces cerevisiae boulardii.

${ }^{2)} \mathrm{CV}$ : coefficient of variation.

\section{Growth performance}

There was no effect of interaction, gender and probiotic source $(p>0.05)$ on the variables $F W$,
DWG, DFI and FC in the pre-starter I, pre-starter I and II, and total period (Table 4). The covariable initial weight was significant in the analysis of 
variance $(\mathrm{p}<0.05)$ for the characteristics $\mathrm{FW}$, DWG, DFI and FC. This demonstrates that there is a need to correct growth performance characteristics by initial weight in experiments with piglets, thus increasing experimental accuracy. Average values of FW during the total nursery period ranged from 21.50 to $22.97 \mathrm{~kg}$. The pigs presented a DWG with values between 0.395 and $0.430 \mathrm{~kg}$, a DFI of 0.529 and $0.553 \mathrm{~kg}$, and a $\mathrm{FC}$ of 1.29 to 1.42 .

Table 4. Lsmeans of final weight, daily feed intake, daily weight gain in $\mathrm{kg}$ and feed conversion of piglets, according to combinations of probiotic and gender classes in Exp. $2^{11}$.

\begin{tabular}{|c|c|c|c|c|c|c|c|}
\hline \multicolumn{8}{|c|}{ Pre-starter I (21 to 29 days of age) } \\
\hline \multirow{2}{*}{ Variable } & \multicolumn{3}{|c|}{ Female } & \multicolumn{3}{|c|}{ Male } & \multirow{2}{*}{ CV $(\%)$} \\
\hline & PF & Probiotic A & Probiotic B & PF & Probiotic A & Probiotic B & \\
\hline FW & 9.30 & 9.34 & 9.11 & 9.19 & 9.21 & 9.37 & 3.84 \\
\hline DWG & 0.262 & 0.265 & 0.236 & 0.252 & 0.250 & 0.266 & 14.72 \\
\hline DFI & 0.315 & 0.340 & 0.319 & 0.306 & 0.316 & 0.327 & 9.72 \\
\hline FC & 1.24 & 1.32 & 1.35 & 1.23 & 1.27 & 1.26 & 11.28 \\
\hline \multicolumn{8}{|c|}{ Pre-starter I e II (21 to 40 days of age) } \\
\hline FW & 13.54 & 13.63 & 13.30 & 13.63 & 13.38 & 13.93 & 4.45 \\
\hline DWG & 0.332 & 0.337 & 0.319 & 0.334 & 0.321 & 0.350 & 8.65 \\
\hline DFI & 0.439 & 0.443 & 0.431 & 0.423 & 0.422 & 0.439 & 8.90 \\
\hline FC & 1.33 & 1.33 & 1.36 & 1.26 & 1.32 & 1.27 & 5.56 \\
\hline \multicolumn{8}{|c|}{ Total period (21 to 63 days of age) } \\
\hline FW & 22.07 & 21.50 & 21.90 & 22.93 & 22.97 & 22.81 & 5.01 \\
\hline DWG & 0.409 & 0.395 & 0.400 & 0.427 & 0.430 & 0.426 & 6.60 \\
\hline DFI & 0.529 & 0.534 & 0.531 & 0.539 & 0.553 & 0.546 & 6.88 \\
\hline FC & 1.35 & 1.42 & 1.36 & 1.29 & 1.32 & 1.32 & 4.31 \\
\hline
\end{tabular}

1) FW: final weight; DWG: daily weight gain; DFI: daily feed intake; FC: feed conversion; Treatments - PF: probiotic free commercial feed $(n=8)$, Probiotic A: commercial feed with addition of $0.2 \%$ probiotic containing a blend of microorganisms $(n=7)$ and Probiotic B: commercial feed with addition of $0.1 \%$ yeast-based probiotic Saccharomyces cerevisiae boulardii $(\mathrm{n}=7)$.

${ }^{2)} \mathrm{CV}$ : coefficient of variation.

There was no effect $(p>0.05)$ of gender on the FW, DWG and DFI of pigs during the pre-starter I and II phases (Table 5). However, in the pre-starter I and II phases, there was a difference $(\mathrm{p}<0.05)$ in $\mathrm{FC}$, in which males presented better results than females, with average values of 1.28 and 1.34, respectively.

Table 5. Lsmeans of final weight, daily feed intake, daily weight gain in $\mathrm{kg}$ and feed conversion of piglets, according to the gender classes in Exp. $2^{11}$.

\begin{tabular}{lcccc}
\hline \multicolumn{5}{c}{ Pre-starter I (21 to 29 days of age) } \\
\hline Gender & FW & DWG & DFI & FC \\
\hline Male & 9.26 & 0.256 & 0.316 & 1.25 \\
Female & 9.25 & 0.254 & 0.324 & 1.30 \\
CV (\%) & 3.84 & 14.72 & 9.72 & 11.28 \\
\hline
\end{tabular}


continuation

\begin{tabular}{lcccc}
\hline \multicolumn{5}{c}{ Pre-starter I and II (21 to 40 days of age) } \\
\hline Male & 13.65 & 0.335 & 0.428 & $1.28^{\mathrm{b}}$ \\
Female & 13.49 & 0.330 & 0.438 & $1.34^{\mathrm{a}}$ \\
CV (\%) & 4.45 & 8.65 & 8.90 & 5.56 \\
\hline \multicolumn{5}{c}{ Total period (21 to 63 days of age) } \\
\hline Male & $0.427^{\mathrm{a}}$ & 0.546 & $1.31^{\mathrm{b}}$ \\
Female & $22.90^{\mathrm{a}}$ & $0.401^{\mathrm{b}}$ & 0.532 & $1.38^{\mathrm{a}}$ \\
CV (\%) & $21.82^{\mathrm{b}}$ & 6.60 & 6.88 & 4.31 \\
\hline
\end{tabular}

${ }^{1}$ Lsmeans values followed by different letters in the column differ from each other, by the F-test, at a 5\% probability level; FW: final weight; DWG: daily weight gain; DFI: daily feed intake; FC: feed conversion; Treatments - PF: probiotic free commercial feed, Probiotic A: commercial feed with addition of $0.2 \%$ probiotic containing a blend of microorganisms and Probiotic B: commercial feed with addition of $0.1 \%$ yeast-based probiotic Saccharomyces cerevisiae boulardii.

${ }^{2)} \mathrm{CV}$ : coefficient of variation.

During the total study period, significant differences were found between gender $(\mathrm{p}<0.05)$ for FW, DWG and FC; males presented better results than females in all variables. There was no significant difference between males and females for the DFI variable.

\section{Discussion}

\section{Digestibility assay}

The highest digestibility of nutrients, attributed to the use of probiotics and antibiotics in feed, could be due to the increased availability of nutrients for uptake, the suppression of metabolic activities and growth of harmful intestinal microbiota, and the simultaneous alteration of the intestinal morphology (SHIM et al., 2010). Bacilli and lactobacilli are known to increase the rate of glucose transport, and increase intestinal villus height and crypt depth, which contribute to improved nutrient uptake in swine (BREVES et al., 2000; RAO; WANG, 2010).

Previous results demonstrated that certain species of microorganisms that are present in probiotics improve the digestion and uptake of some nutrients due to the secretion of amylase, protease and lipase, enzymes that favour the digestion of food (ROBLES-HUYANATE et al., 2014).
Consistent with this study, Robles-Huyanate et al. (2014) studied pigs in the growth phase with a diet containing probiotics based on Bacillus, Lactobacillus, Streptococcus and Saccharomyces, and found no significant differences in digestible nutrients, digestible and metabolisable energy, or the digestibility coefficients in feeds, with the exception of mineral matter, which was absorbed at a higher rate in the probiotic-containing diet.

Ahmed et al. (2014) used antibiotics and probiotics as a food supplement in pigs and reported higher values of apparent digestibility for DM, CP and EE. Meng et al. (2010) and Shim et al. (2010) found better apparent digestibility of DM and CP in pigs supplemented with a probiotic complex.

\section{Microbiological analysis}

This shows that certain species of microorganisms are more efficient at reducing the concentration of some pathogenic bacteria. In the current study, there was no difference $(\mathrm{p}>0.05)$ in the Clostridium count in the faeces from piglets that received diets with or without probiotics. However, the TBC of pigs fed diets containing the probiotic with several species of microorganisms was lower than that of pigs only fed a probiotic. 
Research conducted by Ahmed et al. (2014), which evaluated the microbiology of piglet faeces following the consumption of diets containing a negative control (no addition), positive control (antibiotic addition), probiotic 1 (0.5\% Lactobacillus) and probiotic 2 (0.04\% Bacillus), revealed significant differences in the counts of E. coli, Salmonella typhimurium, Lactobacillus spp. and Bacillus spp; the piglets that received the negative control had worse results than those that received the other treatments. There was no difference between the additives, except in relation to Salmonella, such that the piglets fed with feed containing probiotic 1 presented higher counts than the other two additives.

\section{Growth performance}

It is possible that, because the piglets were housed under conditions of low sanitary challenge, the tested sources of probiotic may not have had a significant effect on the performance of the piglets. In addition, the feeds were iso-nutritional and made from highly digestible ingredients, which may have also contributed to the lack of difference between feeds.

Afonso et al. (2013) found similar values (20.78 to $23.92 \mathrm{~kg}$ body weight) in a study performed on piglets in the nursery phase. In their study, the authors evaluated the inclusion of two probiotics in the diets and observed that up to 54 days of age, the combination of probiotics Lactobacillus reuteri + Bifidobacterium pseudolongum and the probiotic Bacilus subtilis promoted a higher average weight than diets without a probiotic. However, after 54 days of age, the mean weight of the piglets did not differ with the inclusion of probiotics in the diets.

In other research, Papatsiros et al.(2011) evaluated diets supplemented with probiotics for piglets in the nursery phase and found similar values; however, the DWG found by these authors was lower, ranging from 0.343 to $0.362 \mathrm{~kg}$, and the values for FC were higher, ranging from 1.50 to 1.56 , compared to those obtained in the present study.

Junqueira et al. (2009) found no significant effect on the weight gain, feed intake or feed conversion of piglets between 28 and 42 days of age when fed with antibiotic, probiotic (Bacillus toyoi), prebiotic and symbiotic diets.

Entire males, females and barrows show different patterns of growth performance (BRUMANO; GATTÁS, 2009). For example, in pigs in the growing and finishing phases, Guimarães et al. (2011) found worse feed conversion in barrows compared to females. The authors concluded that this was due to the absence of sex hormones in barrows, which increased feed intake and reduced protein deposition in muscle tissues.

Better performance indices have been reported for entire males than females, but only in adult animals. However, in the present research, the difference in growth performance between entire male and female pigs was apparent from the prestarter II phase (from 30 to 40 days of age), possibly due to the activity of masculine sex hormones.

Probiotics added to commercial feeds improved the apparent digestibility of the crude protein of the feed. Piglets fed commercial feed containing probiotics based on the yeast Saccharomyces cerevisiae boulardii showed a reduction in the total bacterial count in the faeces. Commercial feed supplemented with $0.2 \%$ probiotic containing a blend of microorganisms, and commercial feed supplemented with $0.1 \%$ probiotic of yeast Saccharomyces cerevisiae boulardii did not influence the growth performance parameters of piglets during the nursery phase.

\section{Statement of animal rights}

All procedures adopted in this project are in accordance with the guidelines of the Ethics Committee on Animal Use for conducting animal experiments. All techniques were accompanied by trained professionals in the area. 


\section{Conflict of interest statement}

We wish to confirm that there are no known conflicts of interest associated with this publication and there has been no significant financial support for this work that could have influenced its outcome.

\section{References}

AFONSO, E. R.; PARISSA, L. J.; MARINO, C. T.; MARTINS, S. M. K.; SILVA, C. C.; GAMEIRO, A. H.; MORETTI, A. S. A. Associação de probióticos adicionados à dieta de leitões no aleitamento e na creche: índices zootécnicos e economicidade. Revista Brasileira de Saúde Produção Animal, Salvador, v. 14, n. 1, p. 161176, 2013.

AHMED, S. T.; HOON, J.; MUN, H. S.; YANG, C. J. Evaluation of Lactobacillus and Bacillus-based probiotics as alternatives to antibiotics in enteric microbial challenged weaned piglets. African Journal of Microbiology Research, Nigeria, v. 8, n. 1, p. 96-104, 2014.

BREVES, G.; WALTER, C.; BURMESTER, M.; SCHRODER, B. In vitro studies on the effects of Saccharomyces boulardii and Bacillus cereus var. toyoi on nutrient transport in pig jejunum. Journal of Animal Physiology and Animal Nutrition, Berlin, v. 84, n. 1-2, p. 9-20, 2000. DOI: 10.1046/j.1439-0396.2000.00277.x

BRITO, M. B.; PLAZA-DÍAZ, J.; FONTANA, L.; MUÑOZ-QUEZADA, S. In vitro cell and tissue models for studying host-microbe interactions: a review. British Journal of Nutrition, London, v. 109, n. 2, p. 27-34, 2013. DOI: $10.1017 / \mathrm{S} 0007114512004023$

BRUMANO, G.; GATTÁS, G. Fatores que influenciam na exigência de lisina para suínos. Revista Eletrônica Nutritime, Viçosa, MG, v. 6, n. 3, p. 918-940, 2009.

GIANG, H. H.; VIET, T. Q.; OGLE, B.; LINDBERG, J. E. Growth performance, digestibility, gut environment and health status in weaned piglets fed a diet supplemented with a complex of acid bacteria alone or in combination with Bacillus subtilis and Saccharomyces boulardii. Livestock Science, Amsterdam, v. 143, n. 2, p. 132-141, 2012. DOI: 10.1016/j.livsci.2010.01.010

GUIMARÃES, G. G.; MURATA, L. S.; MCMANUS, C.; SANTANA, A. P.; RECKZIEGEL, G. C.; AMÂNCIO, A. S.; JARDIM FILHO, R. M.; SOBRINHO, A. J. F. Desempenho de suínos de dois cruzamentos de linhagens comerciais criados em cama sobreposta. Archivos de Zootecnia, Córdoba, v. 60, n. 229, p. 11-18, 2011. DOI: 10.4321/S0004-05922011000100002
JUNQUEIRA, O. M.; BARBOSA, L. C. G. S.; PEREIRA, A.; ARAÚJO, L. F.; GARCIA NETO, M.; PINTO, M. F. Uso de aditivos em rações para suínos nas fases de creche, crescimento e terminação. Revista Brasileira de Zootecnia, Viçosa, MG, v. 38, n. 12, p. 2394-2400, 2009. DOI: $10.1590 / \mathrm{S} 1516-35982009001200015$

KOTZAMPASSI, K.; GIAMARELLOS, E. J. Probiotics for infectious diseases: more drugs, less dietary supplementation. International Journal of Antimicrobial Agents, Holanda, v. 40, n. 4, p. 288-96, 2012. DOI: 10.1016/j.ijantimicag.2012.06.006

LOJANICA, M.; MANOJLOVIC, M.; JEREMIC, D. The effects of probiotic Enterococcus faecium DSM 7134 in the weaned pigs nutrition. Biotechnology in Animal Husbandry, Zemun, v. 26, n. 1-2, p. 57-64, 2010.

MATTERSON, L. D.; POTTER, L. M.; STUTZ, M. W.; SINGSEN, E. P. Research report 7: the metabolizable energy of feed ingredients for chickens. Hartford: Res. Rep. Conn. Agric. Exp. Stn., 1965. 11p.

MENG, Q. W.; YAN, L.; AO, X.; ZHOU, T. X.; WANG, J. P.; LEE, J. H.; KIM, I. H. Influence of probiotics in different energy and nutrient density diets on growth performance, nutrient digestibility, meat quality, and blood characteristics in growing-finishing pigs. Journal of Animal Science, Champaign, v. 88, n. 10, p. 33203326, 2010. DOI: $10.2527 /$ jas.2009-2308

PAPATSIROS, V. G.; TASSIS, P. D.; TZIKA, E. D.; PAPAIOANNOU, D. S.; PETRIDOU, E.; ALEXOPOULOS, C.; KYRIAKIS, S. C. Effect of benzoic acid and combination of benzoic acid with a probiotic containing Bacillus Cereus var. toyoi in weaned pig nutrition. Polish Journal of Veterinary Sciences, Olsztyn-Kortowo, v. 14, n. 1, p. 117-125, 2011. DOI: 10.2478/v10181-011-0017-8

PEKAS, J. C. Versatible swine laboratory apparatus for physiologic and metabolic studies. Journal of Animal Science, Champaign, v. 27, n. 5, p. 1303-1309, 1968. DOI: $10.2527 /$ jas $1968.2751303 \mathrm{x}$

POWER, S. E.; OTOOLE, P. W.; STANTON, C.; ROSS, R. P.; FITZGERALD, G. F. Intestinal microbiota, diet and health. British Journal of Nutrition, London, v. 111, n. 3, p. 387-402, 2014. DOI: $10.1017 /$ S0007114513002560

RAO, J. N.; WANG, J. Y. Regulation of gastrointestinal mucosal growth. In: GRANGER, D. N.; GRANGER, J. P. (Ed.). Colloquium series on integrated systems physiology: from molecule to function. $2^{\text {th }}$ ed. Califórnia: Morgan \& Claypool Life Sciences, 2010. p. 1-114.

ROBLES-HUAYNATE, R. A.; THOMAZ, M. C.; SANTANA, A. E.; MASSON, G. C. I. H.; AMORIN, A. B.; SILVA, S. Z.; RUIZ, U. S.; WATANABE, P. H.; 
BUDIÑO, E. L. Probiótico em dietas de suínos sobre os parâmetros sanguíneos e digestibilidade de rações. Semina: Ciências Agrárias, Londrina, v. 35, n. 3, p. 1627-1636, 2014. DOI: 10.5433/1679-0359.2014v35n $3 \mathrm{p} 1627$

ROSTAGNO, H. S.; ALBINO, L. F. T.; DONZELE, J. L.; GOMES, P. C.; OLIVEIRA, R. F.; LOPES, D. C.; FERREIRA, A. S.; BARRETO, S. L. T.; EUCLIDES, R. F. Tabelas brasileiras para aves e suínos: composição de alimentos e exigências nutricionais. 3. ed. Viçosa, MG: UFV, 2011. 252 p.

SAKOMURA, N. K.; ROSTAGNO, H. S. Métodos de pesquisa em nutrição de monogástricos. 2. ed. Jaboticabal: FUNEP, 2016. 283 p.

SHIM, Y. H.; SHINDE, P. L.; CHOI, J. Y.; KIM, J. S.; SEO, D. K.; PAK, J. I.; CHAE, J.; KWON, I. K. Evaluation of multi-microbial probiotics produced by submerged liquid and solid substrate fermentation methods in broilers. Asian-Aust. Journal of Animal
Science, Champaign, v. 23, n. 4, p. 521-529, 2010. DOI: 10.5713/ajas.2010.90446

SILVA, N.; JUNQUEIRA, V. C. A.; SILVEIRA, N. F. A. Manual de métodos de análise microbiológica de alimentos. São Paulo: Varala, 1997. 295 p.

SILVA, D. J.; QUEIROZ, A. C. Análise de alimentos: métodos químicos e biológicos. $3^{\text {th }}$ ed. Viçosa, MG: Universidade Federal de Viçosa, 2002. 235 p.

WANG, Y.; CHO, J. H.; CHEN, Y. J.; YOO, J. S.; HUANG, Y.; KIM, H. J.; KIM, I. H. The effect of probiotic BioPlus $2 \mathrm{~B}{ }^{\circledR}$ on growth performance, dry matter and nitrogen digestibility and slurry noxious gas emission in growing pigs. Livestook Science, Amsterdam, v. 120, n. 1, p. 3542, 2009. DOI: 10.1016/j.livsci.2008.04.018

YANG, F.; HOU, C.; ZENG, X.; QIAO, S. The use of lactic acid bacteria as a probiotic in swine diets. Pathogens, Basel, v. 4, n. 1, p. 34-45, 2015. DOI: 10.3390/pathogens4010034 